\title{
Use of an Institutional Personal Learning Environment to support learning actions in Higher Education
}

\section{El uso de un Entorno Personal de Aprendizaje Institucional en apoyo a las acciones de aprendizaje en la Educación Superior}

\author{
Lucila Pérez Cascante ${ }^{1}$, Jesús Salinas ${ }^{2}$, Victoria Marín ${ }^{2}$ \\ ${ }^{1}$ Universidad Casa Grande - UCG, Guayaquil, Equador \\ ${ }^{2}$ Universidad de las Islas Baleares - UIB, Palma, Espanha \\ Mail to/Correo a: Lucila Pérez Cascante (Iperez@casagrande.edu.ec)
}

Submitted/Recibido: 02 Jun. 2016; Approved/Aceptado: 05 Jul. 2016

Copyright (C) 2016 Pérez Cascante, Salinas \& Marín. All journal content (including directions, editorial policy and templates) is under a Creative Commons license Attribution-NonCommercial-ShareAlike 3.0 Non Adapted. By being published by this journal, articles are free to use in educational, research and non commercial environments, with mandatory attribution of authorship. To further information check http://ojs.c3sl.ufpr.br/ojs2/index.php/atoz/about/submissions\#copyrightNotice.

\begin{abstract}
Introduction: This paper presents a pilot experience on the use of an Institutional Personal Learning Environment (iPLE) which aimed to describe the conception, design and development of the iPLE, as well as to determine how users approached the iPLE, and to identify the structure of the Personal Learning Environments (PLEs) designed by students.

Method: The iPLE supported graduated students - specialized on research for social sciences and education -of the University Casa Grande (Guayaquil, Ecuador) - in the development of their final master projects and to support other people interested in building and using a PLE. The experiment data sources included academic records, virtual classrooms design, the very PLEs built by the students, statistics of use and access to the iPLE; and a questionnaire held to the participants.

Results: The initial results allow the research team to report a favourable acceptance of the iPLE by the students not only as a support for research work, but also to provide a model for the construction of PLEs. In addition, the questionnaire shows that the users of the iPLE rated the environment as having high usability and felt a high grade of satisfaction.

Conclusions: The conclusions point out different lines of research related to iPLEs, such as use an IPLE as portfolio of evidence and interaction among students, peers and teachers is the customization of an iPLE by using technological and teaching learning resources.
\end{abstract}

Keywords: Personal Learning Environment (PLE); Personalized Learning; Social Networks; Usability; Open Learning

\begin{abstract}
Resumen
Introducción: En este artículo se presenta una experiencia piloto relacionada con el uso de un Entorno Institucional de Aprendizaje (iPLE), la cual tuvo como objetivo describir la concepción, diseño y desarrollo del iPLE, así como determinar el nivel de aceptación de los usuarios del iPLE, e identificar la estructura de los Entornos de Aprendizaje Personal (PLEs) diseñado por estudiantes.

Metodología: El iPLE está especializado en el área de investigación para las ciencias sociales y la educación, y está orientado a apoyar estudiantes de la Universidad Casa Grande (Guayaquil, Ecuador), en el desarrollo de sus proyectos de final de máster y a apoyar a otras personas interesadas en la creación y utilización de un PLE. Para la recolección de datos se evaluaron los expedientes académicos, las aulas virtuales, los PLEs construidos por los estudiantes, las estadísticas de uso y acceso al iPLE; y los resultados de un cuestionario aplicado a los participantes.

Resultados: Los resultados iniciales señalan una aceptación favorable del iPLE por los estudiantes, porque sirve de apoyo al trabajo de investigación y proporciona un modelo para la construcción de los PLE de los estudiantes. Además, los resultados de la encuesta muestran que los usuarios del iPLE calificaron el ambiente como de alta usabilidad y mostraron un alto grado de satisfacción.

Conclusiones: Las conclusiones señalan diferentes líneas de investigación relacionadas con iPLEs, tales como el uso de un iPLE como portafolio de evidencias e interacción entre los estudiantes, los compañeros y los profesores, o la personalización de un iPLE utilizando diversas estrategias y recursos tecnológicos para el aprendizaje, entre otras.
\end{abstract}

Palabras clave: Entorno Personal de Personal de Aprendizaje (PLE); Aprendizaje personalizado; Redes sociales; Usabilidad; Aprendizaje abierto

\section{INTRODUCTION}

The assessment of the university system of Ecuador has identified as a critical problem the high index of dropouts -especially in the first years- and the low index of end efficiency, with higher incidence in the public universities (Consejo de Evaluación, Acreditación y Aseguramiento de la Calidad [CEAACES], 2013). In previous research, these problems have been related to the standardization of the didactic processes regarding a traditional education based on knowledge transfer and performance, without consideration of the students' needs or alternative learning strategies (Vázquez, Noriega Biggio, \& García, 2013). In order to overcome these negative indicators, the university system must enrich the pedagogical models with differentiated learner centered strategies according to learner's knowledge, competencies and learning preferences.

Personalized learning facilitated by technological resources is a pedagogical proposal that allows students to take control of their learning processes. The current study focuses on determining the potential benefits of an institutional Personal Learning Environment (iPLE) based on the theories of multiple intelligences and the Zone of Proximal Development (ZPD) that can be personalized depending on each student's specific needs. 
More precisely, the study aims to determine if the use of an Institutional Personal Learning Environment (iPLE) can be helpful as a complementary strategy to support graduate students in the process of construction of their research works and creation of their personal, group and community learning spaces.

\section{THEORETICAL FRAMEWORK}

Learning can be defined as a permanent change in behavior as the result of the acquisition of new knowledge and the development of new abilities and skills, which can be observed and measured in terms of performance improvements. According to the cognitive approach, learning can be also considered as the conformation of connections among neurons and knowledge maps that boost new knowledge (Organization for Economic Cooperation and Development [OCDE], 2006). The constructivist paradigm considers learning as an active and student-centered process, in which knowledge is built based on experience created through enough complex activities that represent a challenge to the students without being an obstacle to their learning (Smith \& Ragan, 2005). The connectivist theory, which is considered as a theory for the digital age, puts the learner on the center of learning. This center is generated through the interaction between nodes and networks based on digital contexts, to manage and create new knowledge (Downes, 2007).

According to the theory of multiple intelligences, learning is a unique process in each individual, since each person learns according to the type of intelligence to which they recur in the process (C. Christensen, Horn, \& Johnson, 2011). Vygotsky points out that learning is a sociocultural process leading to intellectual development, where the student's context and social interaction play a key role. He proposes the notion of a ZPD defined as the gap between the real level of development and the potential level of development of an individual with others' support. This support could be offered by using technological resources and personalized learning experiences taking account of each learner's specific needs (Peña-López, 2012).

Different research studies have been conducted on learning personalization supported by digital resources, for instance, by using Learning Management Systems (LMS), learning objects or applications that combine multimedia tools and social networks (Minguillon, Mor, Santanach, \& Guardia, n.d.). In these studies, learners take part in learning activities with greater autonomy and freedom to create the contents and choose time, place and pace of study. Furthermore, they can express their ideas and create what it is relevant to them and their peers (McLoughlin \& Lee, 2010). Overall, the results obtained are positive and highlight potential gains from personalized learning in digital contexts. However, there is still some discussion on its definition, so extending empiric research studies in higher education is recommended (Johnson, Adams Becker, Estrada, \& Freeman, 2015).

Other authors show that current technological resources based on diverse digital tools and social networks allow teachers to personalize learning by planning experiences centered on the students and by considering their level of knowledge, competencies and potential cognitive development (Yang, 2013). The virtual environment where all the required resources for the students converge is called a Personal Learning Environment (PLE) and is defined as a set of learning tools, services and artifacts collected from various contexts to be used by the student to work, learn, reflect and collaborate with others (Attwell, 2010; Mödritscher et al., 2011). Some researchers consider that the PLE is not a particular place or tool that contains all the applications and provides the users with access, but instead a working space to include the chosen web tools and services by the learner to obtain and process information, connect with others and create knowledge. By doing this, students are provided with more control over their learning process (Torres Kompen \& Mobbs, 2008).

From a constructivist perspective, the PLE can boost the Zone of Proximal Development (ZPD) of an individual enabling a multidirectional learning in which the students can use all the available resources and people on the Internet (Peña-López, 2012). At the same time, a PLE removes the learning curve of the typical institutional virtual learning environments (VLE) based on LMS that are limited for learning personalization due to a predefined and closed structure (Torres Kompen \& Mobbs, 2008). Specifically, in the context of higher education, a PLE eases the integration of formal and informal learning with social networks and enhances the development of the users' digital identity (Bustos, Engel, Saz, \& Coll, 2012; Dabbagha \& Kitsantas, 2012; Salinas, 2013).

Some empirical and theoretical studies have been carried out on PLEs in varied contexts. For instance, on the definition of PLE, its origins, its evolution, its pedagogical implications, its supporting technologies and tools, instructional designs based on the concept of PLE and so on. Based on a study of 375 items of literature, Gallego-Arrufat and Chaves-Barboza (2014) analyze the trends in the studies and works related to PLE and point out that PLE is a new concept that demands more empirical research.

The construction of a PLE can be done with the support of different technological tools. The most popular of them are NetVibes, Flock, Plex, Diigo, Elgg, Mahara and SymbalooEDU, among others (Marín, Lizana, \& Salinas, 2014; Skrabut, n.d.). When choosing the elements to create a PLE, (Castañeda \& Adell, 2011) point out that tools and strategies for reading, for reflection, and for connecting with others must be considered. 
These tools and strategies ease the processes of information management, content creation and interaction with others (Marín Juarros, Negre Bennasar, \& Pérez Garcias, 2014).

Some academics promote the integration of the VLE and PLEs as an alternative to get rid of the restrictions of the LMS and use the potential of PLEs to encourage working in open, flexible and personalized environments. In these environments learners have the control and management of their own learning and personal development, going beyond academic training towards lifelong learning (Bustos et al., 2012; Dabbagha \& Kitsantas, 2012; Moccozet, Benkacem, Burgi, Platteaux, \& Gillet, 2012; Peter, Leroy, \& Leprêtre, 2010; Salinas, 2013). Some researchers have named this hybrid environment as iPLE (Casqueroa, Portilloa, Ovelarb, Benitob, \& Romoa, 2010; Peña-López, 2012; Salinas, 2013). Both PLEs and iPLEs are pedagogical strategies with great potential to support learning; however, empirical application to demostrate their benefits still require further experimentation and study (Gallego-Arrufat \& Chaves-Barboza, 2014).

Both from technological and pedagogical approaches, the results of those previous studies confirm that mixed systems that integrate the functions of institutional and personal environments, due to the synergy that they create, offer better conditions for the students' learning in formal and informal contexts and for lifelong learning. These new learning spaces, especially those based on technological development, should be previously validated by potential users - students and teachers-. This validation consists on determining their usability to ensure that each of their components and functionalities meets the objective of enhancing learning in suitable conditions.

The International Organization for Standardization (ISO) defines suitability in terms of effectiveness, efficiency and satisfaction. Concretely, the ISO 9241-11 norm specifies that the usability is the measure in which a product or service can be used to achieve specific objectives with effectiveness, efficiency and satisfaction by certain users in a context defined of use (Bevan, 2009). The definition of usability applied to digital educational applications would mean that these applications should carry out the functions for which they were designed without errors in a set time and should satisfy the users' expectations. In the educational context, different usability studies have been carry out to determine if applications such as learning tools, educational websites, digital libraries, PLEs and others, meet the necessary conditions to fulfil the requirements of potential users and to know their weaknesses and strengths (Conde González \& García-Peñalvo, 2013; Lirola, 2012; Llorente Cejudo, 2013; Marzal, Calzada-Prado, \& Vianello, 2008; Serrano Angulo \& Cebrián Robles, 2014; Toro, 2015).

\section{METHODOLOGY AND RESEARCH DESIGN}

This study focused on three main objectives: a) Identify the nature of use and frequency of use by both the students and teachers of an iPLE specialized for research in social sciences and education; b) Evaluate the structure of student' PLEs and its uses; and c) Determine the iPLE usability and students' satisfaction. It was not intended to analyse the impact of the iPLE on the academic performance or to examine the extent or nature of users' learning. This investigation was conducted in three phases:

a) Design and Construction of the iPLE using the ADDIE method

Although the ADDIE model (Analyze, Design, Develop, Implement, and Evaluate) is an instructional design strategy (Muruganantham, 2015), it can also be used for the development of educational applications. Based upon this consideration, the iPLE was built as follows:

- Analysis. A students' needs analysis was done based on the requirements students have to meet to develop the masters final project.

- Design. The design took into consideration the theories of multiple intelligences and the zone of proximal development as the framework. The specific content included in the iPLE resources, materials and tools was centered on the research field of social science and education. These resources were selected with the support of specialized teachers and researchers.

- Development. The following tools were evaluated in order to choose an appropriate platform to develop an iPLE: Wix, Netvibes, Symbaloo, Flock, Diigo and Elgg. Wix was selected to configure the environment considering that it allows users to create learning site very rich in content and resources from multiple sources based on ready-made templates, which can be adapted according with specific needs and preferences of users. Furthermore, it is easy to use, flexible to organize multimedia resources and to include open web tools, and can be set to allow access from diverse devices Figure 1.

- Implementation. The iPLE was released for a month only for internal users for experimentation and adjustments. The experimental phase was done in the context of the course "Foundations of educational research", in which students were invited to use the iPLE as a support tool for their research assignments. This course has a length of 24 hours and it is taught during a month.

- Evaluation. The iPLE users - during this experimental phase - were asked about the relevance and suitability of the contents, types of resources and ease of use of the iPLE. Feedback was used for adjustment, 
such as the insertion of the options "search site" and the ProQuest service of UCG library that were missing. Furthermore, it was adapted to offer a smartphone version.

b) Launch of the iPLE with open access

The announcement of the iPLE was done through Facebook, Twitter, Scoop.it and ShoutOut, to offer the available resources for research publicly to the target group, who were the students that were attending the Graduate Programs that University Casa Grande offers.

c) Evaluation of the users and iPLE uses

The iPLE is the main resource for students that were writing their master thesis. User information was taken from graduate coordination records. Since the use of the iPLE was extended to other internal users from the University of Casa Grande, virtual classrooms were checked of cooperating teacher who accepted to participate in the experiment. The students' PLEs were also analyzed to determine their structure. Finally, statistics incorporated on the iPLE were also collected to identify the user's location and status (new or return), number of accesses, frequency of use, etc. As a complement, a questionnaire was applied to assess the usability of the iPLE and the users' satisfaction (Pérez, 2015).

The instrument had two sections. The first one measured the usability of the iPLE according to the following four dimensions: Interface, Content, iPLE structure and satisfaction. The Interface dimension had as indicators: presentation, navigation, communication, flexibility and ease of use. The Content dimension had as indicators: quality, pertinence, relevance and usefulness. The Structure dimension of the iPLE had as indicators: platform used and tools, and finally, the Satisfaction dimension did not have indicators. The second section of the questionnaire collected information on the demographical data of the subjects of the sample.

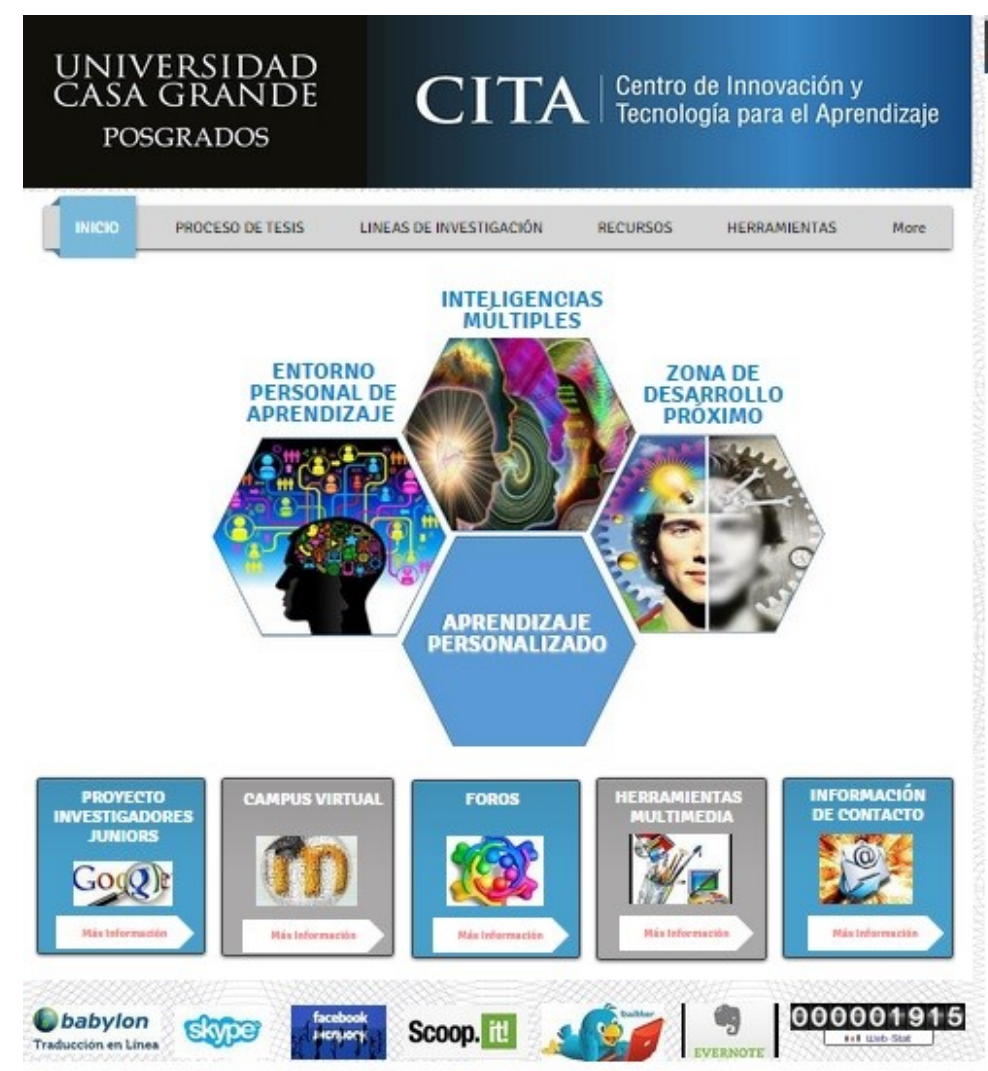

X Create a WiX site!

Figura 1 Pantalla de ingreso al iPLE

Figure 1. Access page to the iPLE.

Source: http://Iperezc2013.wix.com/proceso-tesis-2014.

The questionnaire was validated through expert judgment and calculation of Cronbach's alpha coefficient to determine its reliability. Expert judgment is a procedure where acknowledged experts in the study field take part and has the objective of determining the degree in which the items of an instrument represent the content that the instruments pretend to assess (R. W. Christensen \& Knezek, 2009; Pedrosa, Suárez-Álvarez, \& García-Cueto, 2013). To determine the degree of agreement between the experts' assessments, the following actions were implemented: a) Set the \% of coincidence of the assessment per dimensions and reagents; $b$ ) Calculate the Content Validity Index (CVI) of each item and the General Content Validity Index (GCVI) of the instrument using the Lawshe's method as cited in Pedrosa et al. (2013); and c) Determine Kendall's W to check the level of significance of the agreement. 
Cronbach's alpha coefficient was calculated to determine the level of reliability and internal consistence of the instrument overall and for each one of its dimensions. The value of Cronbach's alpha coefficient of a scale must be equal or higher than 0,8 so that the scale has internal consistence and is reliable. Otherwise, the instrument may generate erroneous results (Creswell, 2009).

\section{RESULTS AND DATA ANALYSIS}

Data collected showed that 397 internal users from different programs offered by the Direction of Graduate Studies have used the iPLE (see Table 1).

\begin{tabular}{ll}
\hline Description & $\mathrm{N}^{\circ}$ \\
\hline In the masters thesis process & \\
Students & 39 \\
Mentors & 22 \\
Evaluators & 16 \\
Educational Technology Masters & \\
$\begin{array}{l}\text { Students } \\
\text { Higher Education Masters }\end{array}$ & 68 \\
Students & 70 \\
Professional Development Program & \\
In-service teachers & 182 \\
Total & 397 \\
\hline
\end{tabular}

Table 1. iPLE users.

To carry out the study, only students in the masters thesis process - from the Educational Technology Masters and Higher Education Masters - were taken into consideration in the sample, since they were the learners that had invested more time with the iPLE and it was considered that their opinion were less subjective and based on a more meaningful experience. Therefore, the sample size is of 146 students, from which the $7 \%$ that are doing their masters thesis, $46 \%$ are enrolled to the Educational Technology Masters and $48 \%$ in the Higher Education Masters.

By gender, the group size is almost the same: $50.7 \%$ are women and $49.3 \%$ are men. By age, the most representative groups are in the range between 30 and 39 years old, which correspond with the $40.4 \%$ of the sample, whereas the range between 40 and 49 years old represents the $27.4 \%$ of the total. Summing these two ranges there is a $68 \%$ of the sample group approximately. The extreme ranges, which are less than 30 years old and more than 40 years old, represent the $23.3 \%$ and the $8.9 \%$, respectively.

By the level of studies, the $89 \%$ have undergraduate studies and the $11 \%$ have already finished their graduate studies. The specialization areas of the studies are: Education (56.2\%), Information Systems (17.8\%), Administration (6.8\%), Social Sciences (4.8\%), Psychology (1.4\%), Medicine (4.8\%) and others (8.2\%). The predominant specialization area is Education, since it has the highest percentage with respect to the other specialization areas. The students in the sample work mainly in universities (38.4\%), High Schools (32.9\%) and businesses (20.5\%). In a lesser amount, some work in schools (7.5\%) and other organizations (0.7\%).

\section{Uses of the iPLE and frequencies of use}

All the students that take part in the graduate programs and professional development programs offered by Universidad Casa Grande used the iPLE, both for the elaboration of the tasks in their studies and for activities of the research courses and works related to other courses.

Between December 2014 and December 2015, 4634 visits to the iPLE were registered, from which the 41.5\% correspond to new users. Therefore, $58.5 \%$ of the visits are from recurrent users, who have used more than once the available resources in the environment (see Figure 2). Being the number of recurrent users higher that the new ones, this means that some users were satisfied and returned to use again the iPLE resources.

It can also be observed that, although the iPLE was developed as resource for the graduate students of Universidad Casa Grande, users from other cities of Ecuador and other countries have taken advantage of it (see Figure 3). According to its source, $87.2 \%$ are local users and $13.8 \%$ from other countries.

Users outside Ecuador come mainly from Spain (3.3\%), the United States (1.9\%), Argentina (1.2\%), Mexico (1\%), Colombia (0.8\%), Chile (0.7\%), Peru (0.7\%) and Venezuela (0.6\%).

\section{Assessment of the students' PLE}

Some of the iPLE of internal users - from Universidad Casa Grande - had to build their own PLE. First, the students had to analyze the iPLE structure and components. Then, from the iPLE they accessed the Wix platform, 

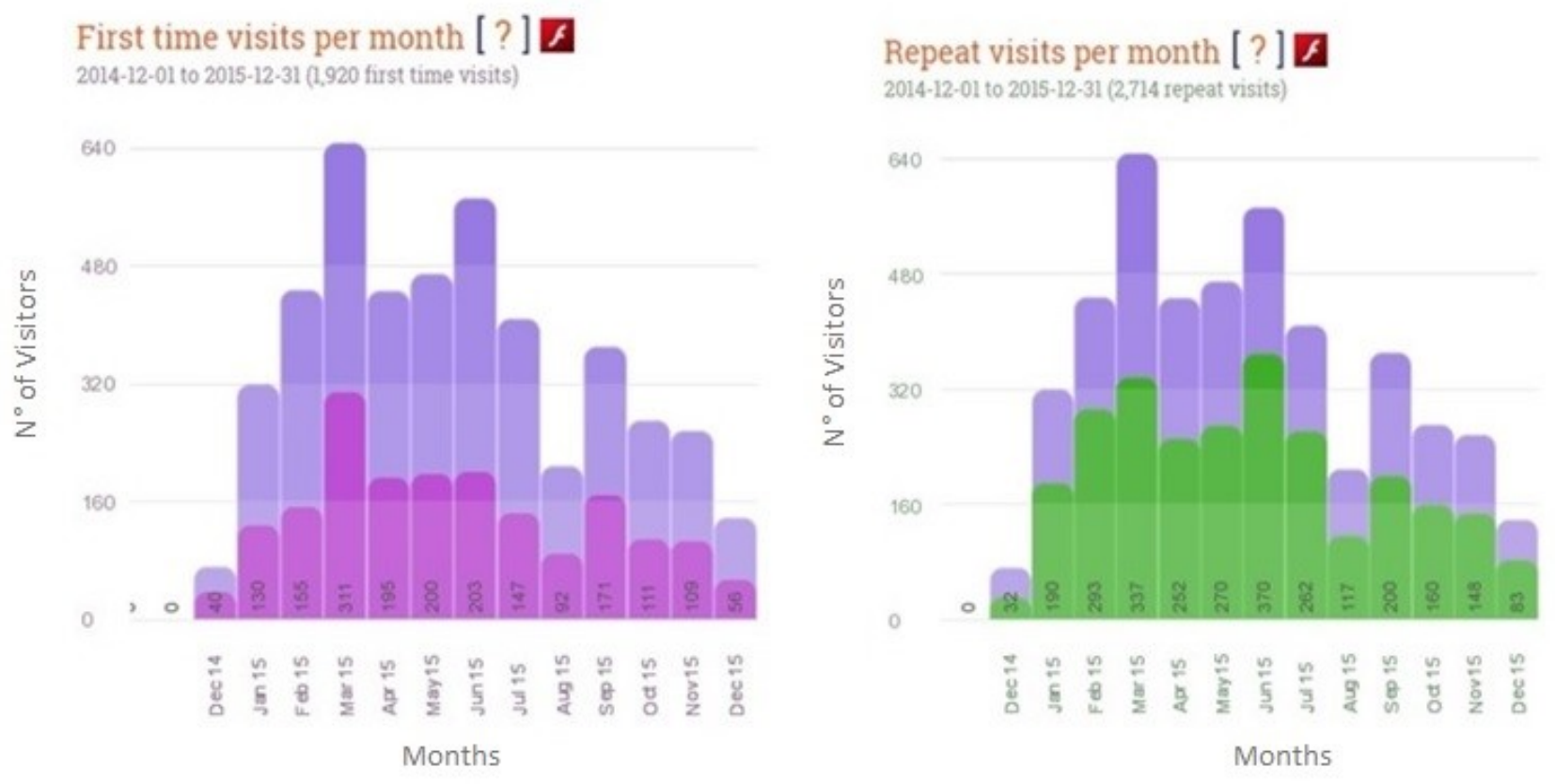

Figure 2. Statistics of new users and recurrent users.

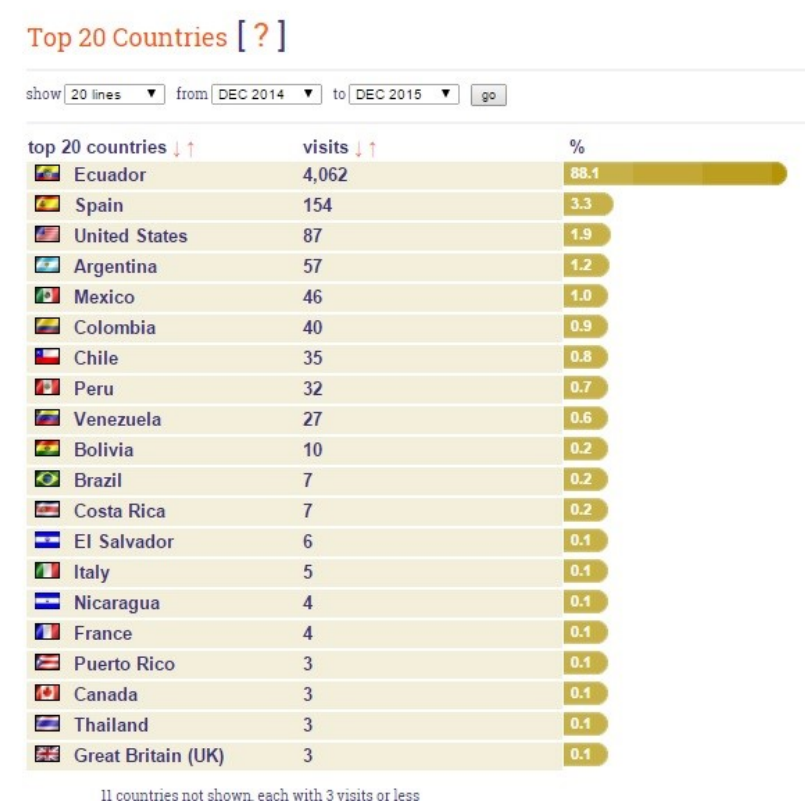

Figure 3. Countries from where the users access to the iPLE.

to create easy-to-personalize pages, where under teacher supervision they could personalize the iPLE or select a Wix template.

From the revision of the students' PLE ${ }^{1}$, it was observed that students used the created PLE mainly as a repository of resources related to their work field and/or interest in multimedia formats. In addition, they used it as e-portfolio for the activities related to their work or academic tasks. The main social media included were (see Figure 4): YouTube (63\%), email (50\%), blog (28\%), Facebook (25\%), Twitter (21\%) and geolocation (18\%).

\section{Usability}

To determine the usability of the iPLE the instrument developed by Pérez (2015) was used, but only the dimensions of Interface, Content and Satisfaction were considered. The Structure dimension was not included because it was only assessed by students of the Educational Technology Masters, who had the creation of a PLE

\footnotetext{
${ }^{1}$ Some examples of students' PLEs:

http://oswaldoarauz.wix.com/ple-de-materias\#!about/cm8a

http://asosa2.wix.com/producciondeaudio

http://janettsm3009.wix.com/janettsm3009
} 


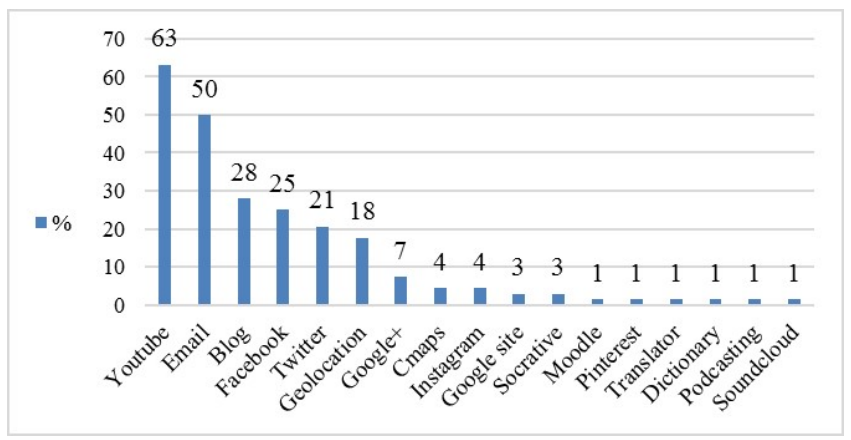

Figure 4. Social media used in the students' PLE.

in the Wix platform and using the iPLE as example as one of their academic activities.

The average usability of the instrument obtained was 4.42 . The Satisfaction dimension obtained a higher value (4.48) and the Interface dimension a lower value (4.33). Overall, they are higher to 4, which show a strong agreement on the characteristics of the iPLE. In Table 2 the information on the average values obtained for each dimension is presented with more detail.

\begin{tabular}{lccccc}
\hline & $\mathrm{N}$ & Minimum & Maximum & Average & SD \\
\hline Interface & 146 & 3.08 & 5.00 & 4.33 & 0.47691 \\
Content & 146 & 2.00 & 5.00 & 4.46 & 0.56261 \\
Satisfaction & 146 & 2.00 & 5.00 & 4.48 & 0.64733 \\
\hline
\end{tabular}

Table 2. Descriptive statistics of the Usability variable per dimensions.

As was previously indicated, the students of the Educational Technology Masters only assessed the Structure dimension of the iPLE. The average assessments of the two indicators that form part of this dimension are almost the same (see Table 3). In consequence, the average assessment of this dimension is similar to their indicators (4.4146).

\begin{tabular}{lccccc}
\hline & $\mathrm{N}$ & Minimum & Maximum & Average & $\mathrm{SD}$ \\
\hline Platform used & 66 & 1.00 & 5.00 & 4.4125 & 0.62907 \\
Tools & 66 & 1.00 & 5.00 & 4.4167 & 0.79703 \\
\hline
\end{tabular}

Table 3. Descriptive statistics of the Structure dimension of the iPLE.

Additionally, the results from the average assessment of the Satisfaction dimension were compared between the three groups of the sample to search for differences. The students doing their master's thesis assessed the Satisfaction dimension with a higher value (4.60) than the other two groups. However, 10 students formed this group, so this result not necessarily could be generalized to other members of the group (see Table 4). Based on this observation, the comparison of the assessment results of the Satisfaction dimension was carried out considering the students of the Educational Technology Masters and the students of the Higher Education Masters, due to their similar quantity of members, 66 in the first and 70 in the second. The value for the assessment of the Satisfaction dimension of the students of the Educational Technology Masters was slightly higher (4.55) than the one of the students of the Higher Education Masters (4.40).

\begin{tabular}{lcc}
\hline & \multicolumn{2}{c}{ Program } \\
\cline { 2 - 3 } & In the masters thesis process & Educational \\
\hline Variable & Average & Average \\
Average Satisfaction & 4.60 & 4.55 \\
\hline
\end{tabular}

Table 4. Comparison among the groups of the Satisfaction variable.

In order to determine if the differences in the assessment of the two groups were significant, the T-Student test for independent samples was applied with a confidence interval of $95 \%$ and an error margin of $5 \%$. The null hypothesis (Ho) was tested "There are not significant differences between the assessments of the groups regarding the Satisfaction dimension". The results show that $\&=0.172$, which is higher than $\&=0.05$, allowed to reject the Ho. In addition, the statistic $t$ value (1.374) is smaller than the critic $t$ (1.960). Based on these results, the null hypothesis is accepted, so the difference between the assessments of the two groups is not significant. The results obtained can be seen in Table 5.

Moreover, if the items of the Satisfaction Dimension are analyzed, it is noticed that the item "I would visit 


\begin{tabular}{lccccc}
\hline $\mathrm{t}$ & $\mathrm{gl}$ & Sig (bilateral) & Mean difference & Difference in standard error & 95\% of interval - Inferior \\
\hline 1.374 & 134 & 0.172 & 0.15660 & 0.11397 & -0.06881 \\
\hline
\end{tabular}

Table 5. T-test for independent samples.

again the iPLE to learn more" has the highest value $(4,51)$. It could be assumed that the iPLE has met the needs of its users (see Figure 5) and they are satisfied with its facilities and resources.

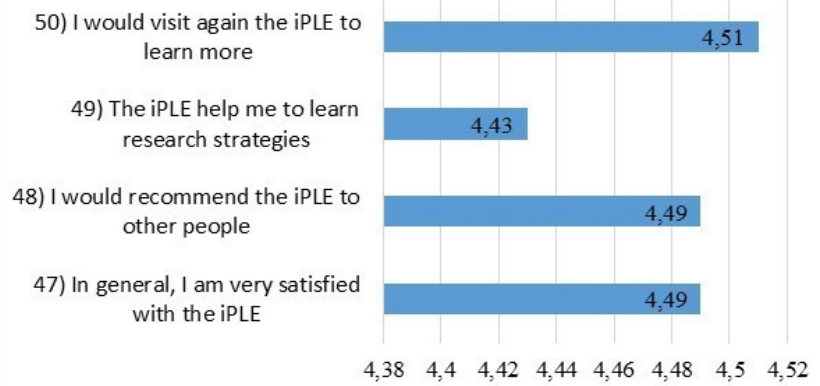

Figure 5. Evaluation of the Satisfaction Dimension.

\section{CONCLUSIONS AND FUTURE DEVELOPMENTS}

Personalized learning has been always a concern for both teachers and researchers from different perspectives. Web based tools, especially social networks, promote personalization of autonomous, collaborative and community learning. Therefore, they have enhanced the construction of new learning spaces like PLEs and iPLEs, spaces to support personalized, open and flexible learning. The iPLE, as a hybrid digital space, promotes the combination of institutional and personal learning and must be designed so that makes it easier for students to access the various tools and resources available in itself and motivate them to use.

Regarding the first objective and based on statistics about access and frequency of use of the iPLE, it can be assumed that student access to bibliographic resources in various digital formats and suitable to their specific needs as well as curated by research specialists was a great support. This is reflected in the number of views of returning visitors that exceeds the number of visits of new users. Moreover, although the main target of the iPLE was the graduate students group, users from other cities in the country and from abroad have also accessed to it. This also allows us to assume that the iPLE meets the requirements regarding the quantity and quality of the tools for the objective group.

The second objective, which was related to the assessment of the construction and use of the students' PLE, we can assume that having an example enhanced the understanding of the theoretical concept behind the environment and its construction. This can be seen from the environments that the students developed and the richness of the content in them. The resources used most often were social networks, which are better known among students, such as Facebook, YouTube, Twitter, among others. It should be observed, however, that some PLEs were developed more as informational websites than as spaces for learning and interaction with peers.

Regarding the third objective, it can be observed that the iPLE created during this research is a highly rated resource to support learning according to the users' assessment. The assessment of the iPLE usability shows a high level of satisfaction of students who have used it both for their tasks in the studies and research courses. It should be highlighted that there were not significant differences in the level of satisfaction among students in the two graduate programs who have used the iPLE. The assessment of the usability for each of its components is similar on average and is placed between the values "agree" or "strongly agree", being the assessment of the interface slightly lower compared to the other components. The assessment of the component "satisfaction", the item that had the highest value was "I would visit the iPLE to learn more". This result allows the researchers to assume - for this group - that objective of the iPLE has been met, which was to enhance autonomous, formal and informal learning in a flexible and open personalized environment.

By the results, it could be said that except from students and some teachers of the Masters in Educational Technology, in general there is not a very clear understanding of the procedures and potential benefits of PLEs and iPLE for learning. Students learned how to build and use the PLE, but as teachers from other courses do not use this approach to learning, most of them did not continue working in this space. Regarding iPLE, students continue to use it in the research courses because the tasks are related to the available resources in this space.

Although there have already been some experiments, iPLE as an evolution of PLE requires further research, both from the technological and pedagogical perspectives. In particular, in the context of higher education in 
Ecuador, PLE and iPLE are still new concepts as strategies to enhance personalized learning.

One possible future work on iPLEs would be related to the use an IPLE as portfolio of evidence and interaction among students, peers and teachers. The current functions of an iPLE do not include the option of e-Portfolio as a space where students can upload their work and that can be shared and/or assessed by their peers. An application with portfolio functions as Mahara (Marín et al., 2014) can be added and assessed the technical and pedagogical functionality of this integration.

Another interesting research and work line is the customization of an iPLE by using technological and teaching learning resources. Personalization of learning by using Learning Objects to support the multiple intelligence of users (Minguillon et al., n.d.) and intelligent tutoring strategies to enhance students' performance (Johnson et al., 2015) are areas of research with a lot of potential to improve learning. However, they still need further empirical work to demonstrate their benefits such as easy creation of learning pathways that meet the unique needs of each student, the characteristics of the competencies to develop and the specificities of the study field or professional development. 


\section{REFERENCES}

Attwell, G. (2010). The future of learning environments. Retrieved from http://www.pontydysgu.org/2010/ 06/the-future-of-learning-environments-short-version/

Bevan, N. (2009). International standards for usability should be more widely used. Journal for Usability Studies, 4(3), 106-113. Retrieved from http://uxpajournal.org/wp-content/ uploads/pdf/JUS_Bevan_May2009.pdf

Bustos, A., Engel, A., Saz, A., \& Coll, C. (2012). Integrating personal and institutional leraning environments. In Proceedings of EDULEARN12 Conference. Barcelona, Spain. Retrieved from http://www.academia.edu/5757502/ Integrating_personal_and_institutional_virtual_learning environments

Casqueroa, O., Portilloa, J., Ovelarb, R., Benitob, M., \& Romoa, J. (2010, Aug.). iPLE Network: an integrated elearning 2.0 architecture from a university's perspective. Interactive Learning Environments, 18(3), 293-308. doi: 10.1080/10494820.2010.500553

Castañeda, L., \& Adell, J. (2011). El desarrollo profesional de los docentes en entornos personales de aprendizaje (PLE). In R. En Roig Vila \& C. Laneve (Eds.), La práctica educativa en la sociedad de la información: Innovación a través de la investigación (pp. 83-95). Alcoy: Marfil. Retrieved from http://mc142.uib.es:8080/rid=1JWP3XF6F -101X2KY-YJP/CastanedaAdell2011preprint.pdf

Christensen, C., Horn, M., \& Johnson, C. (2011). Disrupting class: How disruptive innovation will change the way the world learns. New York: McGraw Hill.

Christensen, R. W., \& Knezek, G. A. (2009, Feb.). Construct validity for the teachers' attitudes toward computers questionnaire. Journal of Computing in Teacher Education, 25(4), 143-155. doi: 10.1080/10402454.2009.10784623

Conde González, M. n., \& García-Peñalvo, F. J. (2013). Entornos de aprendizaje móviles y su aplicación en la enseñanza de ingeniería del software. In II Congreso Internacional sobre Aprendizaje, Innovación y Competitividad. Madrid. Retrieved from http://gredos.usal.es/jspui/bitstream/10366/122585/1/ GRIAL_PaperMobilePLE.pdf

Consejo de Evaluación, Acreditación y Aseguramiento de la Calidad. (2013). Informe final sobre evaluación, acreditación y categorización de las universidades y escuelas politécnicas del ecuador.

Creswell, J. (2009). Research design: Qualitative, quantitative, and mixed methods approaches (3rd ed.). Los Angeles, CA, USA: SAGE.

Dabbagha, N., \& Kitsantas, A. (2012, Jan.). Personal learning environments, social media, and self-regulated learning: A natural formula for connecting formal and informal learning. The Internet and Higher Education, 15(1), 3-8. doi: 10.1016/j.iheduc.2011.06.002

Downes, S. (2007). Learning networks in practice. Retrieved from https://www.academia.edu/2869500/Learning networks_in_practice (National Research Council Publications Records, Canada)

Gallego-Arrufat, M.-J., \& Chaves-Barboza, E. (2014, Sept.). Tendencias en estudios sobre entornos personales de aprendizaje (personal learning environments - PLE. EDUTEC, Revista Electrónica de Tecnología Educativa(49). doi: 10.21556/edutec.2014.49.89

Johnson, L., Adams Becker, S., Estrada, V., \& Freeman, A. (2015). NMC Horizon Report: Edición educación superior 2015.
Austin, TX, USA: The New Media Consortium.

Lirola, F. (2012). Diseño e implementación de un entorno virtual para las titulaciones deportivas del periodo transitorio en los C. A. de las Islas Baleares (Máster en Tecnología Educativa: E-Learning y Gestión del Conocimiento). Universidad de las Islas Baleares, España.

Llorente Cejudo, M. C. (2013). Assessing personal learning environments (PLEs): An expert evaluation. Journal of New Approaches in Educational Research, 2(1), 39-44. doi: 10.7821/naer.2.1.39-44

Marín, V. I., Lizana, A., \& Salinas, J. (2014, Abr.). Cultivando el PLE: una estrategia para la integración de aprendizajes en la universidad. EDUTEC. Revista Electrónica de Tecnología Educativa(47). Retrieved from http://www.edutec.es/revista/ index.php/edutec-e/article/view/127

Marín Juarros, V., Negre Bennasar, F., \& Pérez Garcias, A. (2014, ene.). Entornos y redes personales de aprendizaje (PLE-PLN) para el aprendizaje colaborativo. Comunicar, XXI(42), 35-43. doi: 10.3916/C42-2014-03

Marzal, M. A., Calzada-Prado, J., \& Vianello, M. (2008). Criterios para la evaluación de la usabilidad de los recursos educativos virtuales: un análisis desde la alfabetización en información. Information Research, 3(4). Retrieved from http://informationr.net/ir/13-4/paper387.html

McLoughlin, C., \& Lee, M. J. W. (2010). Personalized and self-regulated learning in the Web 2.0 era: International exemplars of innovative pedagogy using social software. Australian Journal of Educational Technology, 26(1), 28-43. doi: 10.14742/ajet.1100

Mödritscher, F., Krumay, B., Helou, S. E., Gillet, D., Nussbaumer, A., Albert, D., ... Ullrich, C. (2011, Dec.). May I suggest? comparing three PLE recommender strategies. Digital Education Review(20). Retrieved from http://revistes.ub.edu/ index.php/der/article/view/11307

Minguillon, J., Mor, E., Santanach, F., \& Guardia, L. (n.d.). Personalización del proceso de aprendizaje usando "learning objects” reutilizables. Revista de Educación a Distancia(Número Monográfico IV). Retrieved from http://www.um .es/ead/red/M4/minguillon32.pdf

Moccozet, L., Benkacem, O., Burgi, P.-Y., Platteaux, H., \& Gillet, D. (2012). An institutional personal learning environment enabler. In 12th IEEE International Conference on Advance Learning Technologies (pp. 51-52). Rome. doi: 10.1109/ICALT.2012.74

Muruganantham, G. (2015). Developing of E-content Package by using ADDIE model. International Journal of Applied Research, 1(3), 52-54. Retrieved from http://www.allresearchjournal.com/archives/2015/ vol1issue3/PartB/67.1.pdf

Organization for Economic Cooperation and Development. (2006). Schooling for tomorrow - personalising education. Retrieved from http://www.oecd.org/education/school/ 36234148.pdf

Pedrosa, I., Suárez-Álvarez, J., \& García-Cueto, E. (2013). Evidencias sobre la validez de contenido: Avances teóricos y métodos para su estimación. Acción Psicológica, 10(2), 3-18. doi: 10.5944/ap.10.2.11820

Peña-López, I. (2012, Aug. 31). Personal learning environment and the Revolution of Vygotsky's Zone of Proximal Development. Retrieved from http://ictlogy.net/ 20120831-personal-learning-environments-and-the -revolution-of-vygotskys-zone-of-proximal-development/ 
Peter, Y., Leroy, S., \& Leprêtre, E. (2010). First steps in the integration of institutional and personal learning environments. Retrieved from http://3s-cms.enstb.org/futurelearning/wp -content/uploads/2010/09/Yvan_Peter_et_al.pdf

Pérez, L. (2015). Uso del iPLE en el aprendizaje. In XVIII Congreso Internacional de EDUTEC. Riobamba, Ecuador.

Salinas, J. (2013). Enseñanza flexible y aprendizaje abierto, fundamentos clave de los PLEs. In L. Castañeda \& J. Adell (Eds.), Entornos personales de aprendizaje: Claves para el ecosistema educativo en red (pp. 53-70). Alcoy: Marfil. Retrieved from http://digitum.um.es/xmlui/bitstream/10201/30410/1/ capitulo3.pdf

Serrano Angulo, J., \& Cebrián Robles, D. (2014). Usabilidad y satisfacción de la e-Rúbrica. Revista de Docencia Universitaria, 12(1), 177-195. Retrieved from http://red-u.net/redu/ documentos/vol12_n1_completo.pdf

Skrabut, S. (n.d.). Personal learning environments: The natural way of learning. Retrieved from http://www.uwyo.edu/ skrabut/docs/aded5050_project.pdf

Smith, P., \& Ragan, T. (2005). Instructional design. New Jersey: John Wiley \& Sons.

Toro, G. (2015). Forma y usabilidad de un recurso educativo exprofeso: Biblioteca digital en promoción de la salud. Revista Interamericaca de Bibliotecología, 38(1), 4153. Retrieved from http://www.scielo.org.co/pdf/rib/v38n1/ v38n1a3.pdf

Torres Kompen, R., \& Mobbs, R. (2008). Building web 2.0based personal learning environments: A conceptual framework. Retrieved from https://lra.le.ac.uk/bitstream/2381/4398/1/ EDEN\%20ResWksp\%202008\%20Torres\%20Kompen\%20et\% 20al\%20Web\%202.0\%20PLE\%20paper.pdf (EDEN Research Workshop, Paris)

Vázquez, S. M., Noriega Biggio, M., \& García, S. M. (2013). Relaciones entre rendimiento académico, competencia espacial, estilos de aprendizaje y deserción. Revista Electrónica de Investigación Educativa, 15(1), 29-44. Retrieved from http://redie.uabc.mx/redie/article/view/328

Yang, H. H. (2013, Apr.). New world, new learning: Trends and issues of e-learning. Procedia - Social and Behavioral Sciences, 7(22), 429-442. Retrieved from 10.1016/j.sbspro .2013 .03 .098

How to cite this article (APA):

Pérez Cascante, L., Salinas, J. \& Marín, V. (2016). . AtoZ:

novas práticas em informação e conhecimento, 5(1), 53 -

63. Retrieved from: http://dx.doi.org/10.5380/atoz .v5i1.46937 